\title{
BIOAVAILABILITY AND OCULAR DISPOSITION OF KETOROLAC TROMETHAMINE FROM VARIOUS OPHTHALMIC PREPARATIONS
}

Hamdy M. Abd El-Aleem ${ }^{1}$, Farouk M. Sakr ${ }^{1}$, Osama A. Soliman ${ }^{1}$, Hatem, El-Awady ${ }^{2}$ and Germeen N. Salama ${ }^{1}$

${ }^{1}$ Department of Pharmaceutics, Faculty of Pharmacy, Mansoura University, Mansoura, Egypt

${ }^{2}$ Ophthalmic Center, Faculty of Medicine, Mansoura University, Mansoura 35516, Egypt

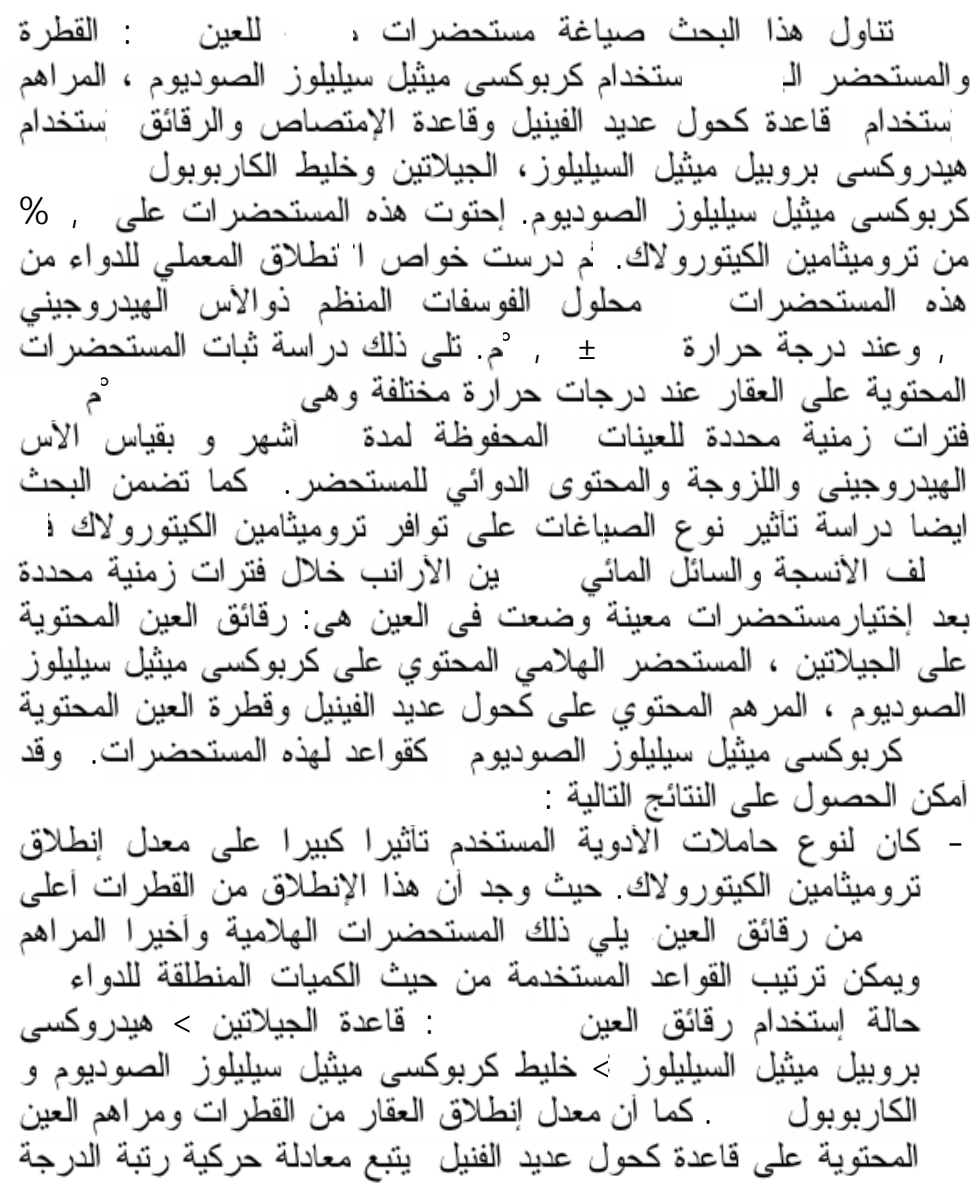


الاولى بينما معدل إنطلاقه من المستحضر ات الهلامية الاخرى يتبع معادلة

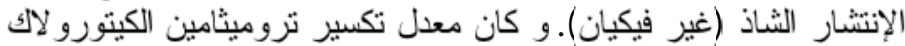

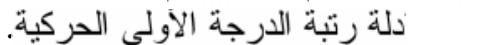

† † ثبات العقار في الصباغات المنباينة و المحتوية على : كربوكسى ميثيل

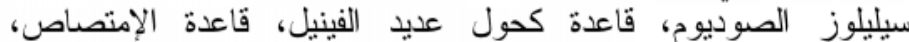
هيدروكسى بروبيل ميثيل السيليلوز، الجيلاتين وخليط كربوكسى ميثيل الئيل

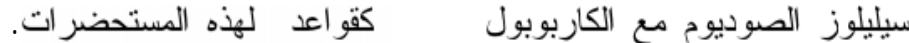

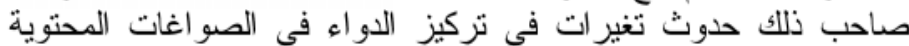

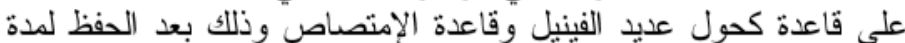

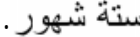

مَّ أن الوقت اللازم للحصول على اعلى تركيز يصل إليه الدواء في الانسجة

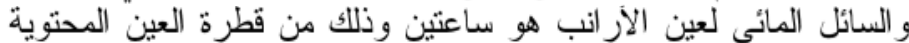

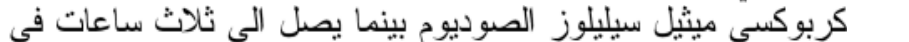

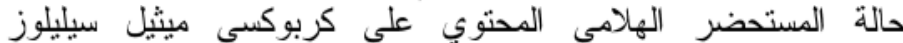

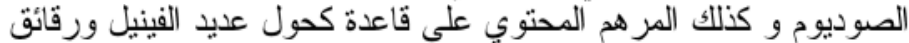

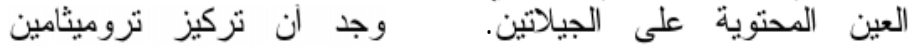

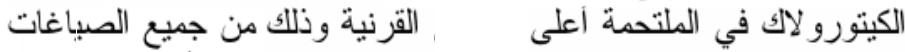

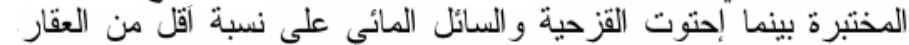

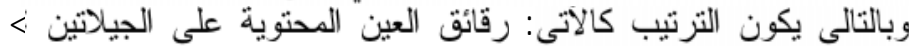

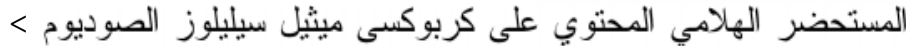
المرهم المحتوي على قاعدة كحول عديد الفينيل > قطرة العين المحتوية العبونية على كربوكسى ميثيل سيليلوز الصوديوم.

Ketorolac tromethamine was formulated in different ophthalmic preparations namely; eye drops, gels, ocuserts and ointments using the following carriers; sodium carboxymethyl cellulose (sod. $C M C)$, polyvinyl alcohol (PVA), hydroxypropylmethyl cellulose (HPMC), absorption base and gelatin. The ophthalmic formulations were prepared containing $0.5 \%$ of the drug. All prepared formulae containing the drug were subjected to stability study and release characteristics. Also, the effect of these drug carriers on the uptake and ocular disposition of ketorolac tromethamine by the eye tissues of rabbits (conjunctiva, cornea, iris-ciliary body and aqueous humor) was studied.

The obtained results revealed that, the released amounts from the ophthalmic preparations after six hours can be arranged in the following order; Eye drops > ocuserts > gel > ointments. Sod CMC eye drops exhibited the higher rate of release than sod CMC gel, PVA and absorption base ointments. Gelatin ocuserts exhibited the higher rate of release than HPMC ocuserts and carbopol 934 \& sod CMC ocuserts. The release rate of the drug from eye drops and 
PVA ointment obeys first order kinetics, while, other preparations obey Higuchi diffusion model with non-Fickian kinetics.

Most formulations (including eye drops) could be stored for 6 months at $25^{\circ} \mathrm{C}, 35^{\circ} \mathrm{C}, 45^{\circ} \mathrm{C}$ without physical or chemical degradations of the drug. However, PVA and absorption bases showed some changes in the drug content ( $t_{90}$ was 2.84 months for both at $45^{\circ} \mathrm{C}$ ). The decomposition rate of ketorolac tromethamine followed the first-order degradation kinetic. The highest stable formulae are, sod CMC eye drops and gel ( $t_{90}$ values were, 151.9 and 91.18 months, respectively at $45^{\circ} \mathrm{C}$ ). The highest concentration of the drug (Cmax) from all tested formulations is provided in conjunctiva followed by cornea, iris-ciliary body, then aqueous humor. The peak time for maximum drug concentration (Tmax) from sod CMC eye drops was two hours. While, that for sod CMC gel, PVA ointment and gelatin ocuserts was three hours in all tissues after the application of the tested formulations. In addition, the total availability of the drug from the tested formulations was in the following order: gelatin ocuserts > sod CMC gel > PVA ointment > sod. CMC eye drops.

\section{INTRODUCTION}

The topical application of ophthalmic preparations is considered the preferred way to achieve the therapeutic levels of drug used to treat the ocular diseases. Ocular bioavailability of drugs from eye drops is poor, due to pre-corneal loss factors, including tear dynamics, nonproductive absorption, transient residence time in the cul-de-sac, and the relative impermeability of the corneal epithelial membrane. Only, a small fraction of a topically applied dose reaches the inner eye with the actual amount dependent on the physicochemical properties of the drug and its vehicle ${ }^{1}$.

An ideal ocular drug-delivery system should be able to control the delivery of drugs of varying physicochemical properties and provide sustained therapeutic action. In order to overcome the large drainage factor imposed by the eye and compensate, at least in part, for the low permeability of corneal tissues, several strategies have been explored to develop extendedduration drug delivery systems. These include, boosting the eye drop viscosity or using ointments and gels as conventional improvements on eye drops. Also, controlled/continuous drug delivery systems including ocuserts was developed and under developed ${ }^{2}$.

Various types of vehicles were investigated in the rabbits eye tissues, for their ability to maintain ocular residence time of some drugs such as 
sodium cromoglycate. Drug disposition in various ocular tissues and fluid compartments is discussed for each type of vehicle. The oleaginous base was found to concentrate the drug in the conjunctiva more than other eye tissues $^{3}$.

ketorolac tromethamine is a non steroidal anti-inflammatory agent that inhibits the activity of cyclooxygenase, one of the two major enzymes responsible for the conversion of arachidonic acid to inflammatory substances. Also, it is effective in relieving ocular itching and the hallmark symptoms of allergic conjunctivitis ${ }^{4}$.

Madhu, et al. ${ }^{5}$, evaluated the effect of benzalkonium chloride/ ethylene diamine tetraacetic acid (BAK/EDTA) on the ocular bioavailability of ketorolac tromethamine following ocular instillation to normal and de-epithelized cornea of rabbits eyes. They concluded that, the ocular bioavailability was not altered by BAK/EDTA in rabbits with intact cornea, but it was decreased by BAK/EDTA in rabbits with deepithelized cornea.

Ling \& Combs ${ }^{6}$, studied the ocular bioavailability and tissue distribution of ketorolac tromethamine in rabbits following the instillation of radiolabeled ophthalmic solutions $\left[{ }^{14} \mathrm{C}\right]$. Also, Malhotra \& Majumdar ${ }^{7}$, studied in vivo ocular availability of ketorolac following ocular instillation of aqueous, oil, and ointment formulations to normal corneas of rabbits.
The aim of this work was to formulate ketorolac tromethamine in various ophthalmic preparations (drops, gel, ointments and ocuserts). All the prepared formulae were subjected to the study of the release characteristics and stability of the tested drug at different storage conditions.

Also, the determination of the drug concentration in different eye tissues (conjunctiva, cornea, irisciliary body, and aqueous humor) using certain selected preparations at different time intervals were be of our goal.

\section{EXPERIMENTAL}

\section{Materials}

- Ketorolac tromethamine (Ranbaxy Laboratories, Ltd., New Delhi, India).

- Sodium carboxymethyl cellulose, propylene glycol, potassium dihydrogen phosphate and gelatin (S.D. fine chemicals, Mumbai, India)

- Sodium dibasic phosphate (Prolabo, Paris, France)

- Hydroxypropylmethyl cellulose (Dow Chemical Company, U.S.A).

- Carbopol 934, polyvinyl alcohol, lanolin (B.P.), yellow soft petrolatum, benzalkonium chloride disodium edetate, sodium metabisulphite (BDH Chemical Ltd, G.B. Liverpool, England).

- Ethyl acetate, N-hexane, methanol (Adwic, El Nasr pharmaceutical chemicals, Co., Egypt). 
- Cellulose membrane, spectrapore, M.W., cut off 12000-14000 (Fisher Sci. Co., Pittsburgh, U.S.A).

- Experimental animals: albino rabbits of $1.8-2 \mathrm{~kg}$.

- All other chemicals and solvents were of analytical reagent grade.

\section{Equipment}

- U.V. spectrophotometer (Shimadzu, UV-150-02, Sersakusho, Ltd, Kyoto, Japan).

- pH-meter (Beckman Instruments fullerton, CA 92634, U.S.A).

- Rotary viscometer (Haake Inc., Germany).

- MSE minor centrifuge (MSE scientific instruments, Manor Royal, Crawley RH/0200 Sussex, England).

- Thermostatically controlled shaking water bath (Grant instrument Cambridge Ltd., Barrington Cambridge B2, 5002, England).

- Ovens (Gering model SPA-Gelman, Instrument No. 16414, Germany)

\section{Methodology}

Preparation of sodium carboxymethyl cellulose eye drops

Ketorolac tromethamine was dissolved in double distilled water in a concentration of $0.5 \% \mathrm{w} / \mathrm{v}$ in which $0.01 \%$ benzalkonium chloride, $0.03 \%$ sodium metabisulphite and $0.1 \%$ EDTA were previously dissolved. This was done by the aid of a high speed stirrer until complete dissolution. Then, sod CMC polymer was added in a concentration of
$0.25 \%$ on the surface of the previous solution. The mixture was stirred until complete dissolution (Table 1).

\section{Preparation of sodium carboxy- methyl cellulose gel}

Ketorolac tromethamine was dissolved in water in which $0.01 \%$ benzalkonium chloride, $0.03 \%$ sodium metabisulphite and $0.1 \%$ EDTA were previously dissolved, by the aid of a high speed stirrer, until a solution is formed, then sod CMC was added to the surface of the previous solution in the concentration of $2.1 \%$ which gave a gel with good rheological properties (Table 1).

\section{Preparation of ointments}

\section{Preparation of polyvinyl alcohol ointment}

Ketorolac tromethamine was dissolved in the water firstly by the aid of a high speed stirrer, until a solution was formed; then, PVA was added with gentle heating in a water bath, until the required ointment was obtained (Table 1).

\section{Preparation of absorption base ointment}

The ointment was prepared firstly by fusion method using $10 \%$ lanolin, $90 \%$ petrolatum. Then, the drug was added to the melted base using geometrical mixing at low temperature with continuous stirring on cold until obtaining a homogenous distribution of the drug in the ointment (Table 1). 
Table 1: The composition of ketorolac tromethamine ophthalmic preparations in a percent of $w / w$.

\begin{tabular}{|l|c|c|c|c|c|c|c||}
\hline \multirow{2}{*}{ Formulation } & Drops & Gel & \multicolumn{2}{|c|}{ Ointment } & \multicolumn{3}{c|}{ Ocuserts } \\
\cline { 2 - 8 } & $\begin{array}{c}\text { Sod } \\
\text { CMC }\end{array}$ & $\begin{array}{c}\text { Sod } \\
\text { CMC }\end{array}$ & PVA & $\begin{array}{c}\text { Lanolin- } \\
\text { petrolatum }\end{array}$ & HPMC & Gelatin & $\begin{array}{c}\text { Carbopol } \\
934 \text { sod } \\
\text { CMC }\end{array}$ \\
\hline $\begin{array}{l}\text { Ketorolac } \\
\text { tromethamine }\end{array}$ & 0.5 & 0.5 & 0.5 & 0.5 & 0.5 & 0.5 & 0.5 \\
\hline Sod CMC & 0.25 & 2.1 & & & & & 1.2 \\
\hline PVA & & & 15 & & & & \\
\hline $\begin{array}{l}\text { Yellow soft } \\
\text { paraffin }\end{array}$ & & & & 89.36 & & & \\
\hline Lanolin & & & & 10 & & & \\
\hline HPMC & & & & & 5 & & \\
\hline $\begin{array}{l}\text { Propylene } \\
\text { glycol }\end{array}$ & & & & & 20 & 20 & 20 \\
\hline Gelatin & & & & & & 5 & \\
\hline Carbopol 934 & & & & & & & 0.5 \\
\hline Distilled water & 99.11 & 97.26 & 84.36 & & 74.36 & 74.36 & 77.66 \\
\hline \hline
\end{tabular}

Where;

Sod CMC $=$ sodium carboxymethyl cellulose

PVA $=$ polyvinyl alcohol

HPMC = hydroxypropylmethyl cellulose

Benzalkonium chloride, sodium metabisulphite and EDTA were added in concentrations of $0.01,0.03$ and $0.1 \%$, respectively.

\section{Preparation of ketorolac trom- ethamine ocuserts}

Ketorolac tromethamine $0.5 \%$ was dissolved in $20 \mathrm{ml}$ distilled water. This solution was added to solutions of HPMC $(5 \% \mathrm{w} / \mathrm{v})$, mixture of Carbopol $934 \quad 0.5 \% \quad w / v \quad \& \quad 1.2 \%$ $(\mathrm{w} / \mathrm{v})$ of sod CMC or gelatin $(5 \%$ $\mathrm{w} / \mathrm{v})$. These solutions contain $0.01 \%$ benzalkonium chloride, $0.03 \%$ sodium metabisulphite and $0.1 \%$ EDTA. Then $20 \mathrm{ml}$ of propylene glycol was added to the same solution. Equal volumes of the prepared solutions were transferred into polytetrafluorethylene (PTFF) moulds. Each mould was covered with an inverted funnel (stem orifice diameter $6.9 \mathrm{~mm}$ ) to control solvent evaporation. The solvent was 
permitted to evaporate for 48 hours at ambient temperature. The formed films were transferred to desiccators containing silica gel, where it was stored for another 24 hours before use $^{8}$. The prepared ocuserts $0.4-0.5$ $\mathrm{mm}$ thickness) were cut in the form of circular discs, each of one $\mathrm{cm}$ diameters. The ocuserts were individually sealed in foil sachets until used (Table 1).

Physicochemical properties of the ophthalmic preparations

Determination of the viscosity of prepared ophthalmic preparations

The viscosity values of different preparations (eye drops, gel and ointments) were determined using rotary viscometer which has been calibrated before use. The temperature was maintained at $37^{\circ} \mathrm{C} \pm 0.5^{\circ} \mathrm{C}$. One gram of each formulation containing the drug was placed on the plate of viscometer (2.9 $\mathrm{cm}$ in diameter) and Cone $(2.8 \mathrm{~cm}$ in diameter). The torque values (S) were determined for each "N" value (speed). Then, viscosity is calculated using the following equation:

$$
\eta=\frac{\mathrm{G} . \mathrm{S}}{\mathrm{N}}
$$

Where;

$\eta=$ Viscosity in mpa.s (mpa. $\mathrm{s}=1$ centipoise)

$\mathrm{G}=$ Instrumental factor $=14200$ (mpa.s/scala grad. minute)

$\mathrm{S}=$ Torque (scale grad.)

$\mathrm{N}=$ Speed (rpm)
Determination of $\mathrm{pH}$ of the prepared formulations

One gram of each formula was dispersed in $30 \mathrm{ml}$ of distilled water. The $\mathrm{pH}$ was determined using $\mathrm{pH}$ meter. For ocuserts, one ocusert of each preparation was used.

Determination of ketorolac tromethamine content in the prepared formulations

One gram from each formula was accurately weighed and placed in a tightly closed volumetric flask containing phosphate buffer $\mathrm{pH} 7.4$ and was heated at $37^{\circ} \mathrm{C} \pm 0.5^{\circ} \mathrm{C}$ on a thermostatically controlled water bath. Then, the volume was completed to $100 \mathrm{ml}$ with the buffer and the contents of each flask were shaken for 15 minutes. Then, $10 \mathrm{ml}$ was taken, and centrifuged. Then the supernatant was filtered and measured at $\lambda_{\max } 322 \mathrm{~nm}$. For ocuserts, one ocusert of each preparation was used to determine its drug content.

\section{In-vitro release study of ketorolac tromethamine from different ophthalmic preparations}

The release of the drug from ophthalmic preparations was carried out using the dialysis method ${ }^{9}$. Five grams of ketorolac tromethamine eye drops, gel and ointments were accurately weighed and spread on a cellophane membrane to occupy a circle of $5 \mathrm{~cm}$ in diameter (or three ocuserts). The loaded membrane was previously soaked in a sufficient amount of the dissolution medium which is phosphate buffer of $\mathrm{pH}$ 7.4. 
The loaded membrane with the eye drops, gel, ointments or ocuserts was stretched over one end of a dialysis glass tube which was made water tight by a rubber band. The inverted tubes were suspended so that, the membrane was just below the surface of $100 \mathrm{ml}$ of phosphate buffer of $\mathrm{pH}$ 7.4 at $37^{\circ} \mathrm{C} \pm 0.5^{\circ} \mathrm{C}$ contained in a beaker of $250 \mathrm{ml}$ capacity.

Samples each of one $\mathrm{ml}$ were withdrawn from the dialysis glass beakers after time intervals: $5,10,20$, $30,60,120,180$, and 240, 300 and 360 minutes. The volume of the dissolution medium in the beaker was compensated by adding an equal volume of phosphate buffer $\mathrm{pH} 7.4$ directly after withdrawal of each sample. The samples were diluted with buffer solution $\mathrm{pH} 7.4$, and then measured spectrophotometrically at $\lambda_{\max } 322 \mathrm{~nm}$. The concentrations were calculated on the basis of the standard calibration curve. Blank experiments were carried out using non-medicated formulations and served as control. The experiments were triplicated and the average of three determinations for the amount of drug released was graphically illustrated as a function of the time.

\section{Stability study}

The ophthalmic formulations were subjected to accelerated stability study at 25,35 and $45^{\circ} \mathrm{C}$ for six months. Samples were withdrawn at predetermined time intervals; $1,2,3$, 4, 5, and 6 months, then examined for physical characteristics (appearance, $\mathrm{pH}$ and viscosity), release profiles and drug content which were measured spectrophotometrically at $\lambda \max _{\text {max }} 322$ $\mathrm{nm}$. Also, the kinetic study of the drug in the pharmaceutical preparations was investigated ${ }^{10}$.

\section{In-vivo study of ketorolac tromethamine from different ophthalmic preparations in rabbits eyes}

\section{Tested formulations}

The following preparations were selected according to the drug released and stability of ketorolac tromethamine at different conditions.

1- $0.5 \%(\mathrm{w} / \mathrm{v})$ ketorolac tromethamine in sod. CMC eye drops.

2- $0.5 \%(\mathrm{w} / \mathrm{w})$ ketorolac tromethamine in sod. CMC gel.

3- $0.5 \% \quad(\mathrm{w} / \mathrm{w})$ ketorolac tromethamine in PVA ointment.

4- $0.5 \% \quad(\mathrm{w} / \mathrm{w})$ ketorolac tromethamine in gelatin ocusert.

Construction of calibration curve of ketorolac tromethamine in rabbits eyes tissues extract

Fifty $\mathrm{mg}$ of the drug was dissolved in $100 \mathrm{ml}$ filtered extract of separated rabbits' eye tissues and aqueous humor to give a concentration of 500 $\mu \mathrm{g} / \mathrm{ml}$. This rabbits eye extract was prepared by extracting the ground rabbits eye tissues twice with $5 \mathrm{ml}$ of mixture composed of ethyl acetate and $\mathrm{n}$ - hexane in a ratio of 30:70, respectively. These combined extracts were evaporated, then the residues were reconstituted in one $\mathrm{ml}$ of methanol. The solutions were centrifuged and filtered. Different volumes of this prepared stock 
solution were transferred to volumetric flasks, each completed to $25 \mathrm{ml}$ with the extract to give concentrations of $2,4,6,8,10,12$, 14, 16, 18 and $20 \mu \mathrm{g} / \mathrm{ml}$. Ultraviolet absorbance of the different concentrations were measured at the predetermined $\lambda_{\max } 322 \mathrm{~nm}$. The obtained results showed a direct relationship between the concentrations and absorbance values $^{11}$.

\section{Application of ketorolac tromethamine formulations into rabbits eyes}

Individual doses of $100 \mathrm{mg}$ of each preparation were accurately weighed (eye drops, gel, ointment or one gelatin ocusert), then immediately and carefully transferred by microspatula into the center of the lower lid (cul-de-sac) of each eye of the albino rabbits weighed 1.8-2 $\mathrm{kg}$. The lower eyelid was gently moved to spread the dose on corneal surface. During dosing, care should be taken not to irritate the eye or touch the corneal surface. All rabbits were kept in upright position in restraining boxes. Four rabbits were used for determination of the amount of drug disposed in different eye tissues and aqueous humor at each time interval.

Ketorolac tromethamine ocular concentration was determined at 1, 2, 3 , and 5 hours after drug application. Therefore, four eyes which received the medicament in each tested formula were used for determination of drug concentration. For each animal, one eye was loaded with the tested formulation, while, the other was loaded with the plain vehicles and served as a control.

\section{Separation of eye tissues}

Following the killing of the rabbits and separation of their conjunctival surfaces, one $\mathrm{ml}$ of aqueous humor was aspirated from the anterior chamber using micrometer syringe. Then, a single incision was made with a scalpel at the corneal margin and the entire cornea was excised. The whole cornea and conjunctival surfaces were rinsed with the least amount of normal saline. The anterior segment tissues; conjunctiva, cornea, iris-ciliray body and aqueous humor was obtained in that order. The surgical procedures on each eye were completed within 10 minutes of sacrificing the animal. So that, any error due to redistribution of the drug during the time required obtaining ocular tissue samples were minimized. Each individual tissue was transferred into scintillation vial and the net weight of tissue was determined using an analytical balance.

Extraction of ketorolac tromethamine from different tissues and fluid of rabbits eyes

The concentration of ketorolac tromethamine in different eye tissues and fluid was determined after 1, 2, 3 and 5 hours of the application of each formulation. At each time interval, conjunctiva, cornea, and iris-ciliary body of each eye were separated immediately, rinsed with isotonic saline solution weighed and ground 
with powdered glass. The ground tissues were extracted twice with $5 \mathrm{ml}$ of mixture composed of ethyl acetate and $\mathrm{n}$ - hexane in a ratio of 30:70, respectively ${ }^{6}$. On the other hand, an aqueous humor was mixed twice with $5 \mathrm{ml}$ of the extracting solvent. These combined extracts were evaporated, and then the residues were reconstituted in one $\mathrm{ml}$ of methanol.

The solutions were centrifuged at $9000 \mathrm{rpm}$ for 30 minutes. After that, filtered using $0.45 \mu \mathrm{m}$ millipore filters. This solution was used for the determination of ketorolac tromethamine concentration in each rabbit's eye tissues at each time interval.

Determination of ketorolac tromethamine in rabbit's eye tissues and fluid from different ophthalmic preparations

The determination of drug concentrations in different eye tissues and fluid had been done by taking the supernatant and measuring the drug at $\lambda_{\max } 322 \mathrm{~nm}$ using UV spectrophotometer. Each sample was run in triplicate. The drug concentration was calculated from the calibration curve. The spectrophotometeric method reported by Bushby and Hitching ${ }^{12}$.

Soliman ${ }^{11}$, determined the ocular disposition of sulfamethoxazole and trimethoprine mixture in rabbit's eyes using spectrophotometeric method. Recently, El-Dahan ${ }^{13}$, also, proved that, the spectrophotometeric method used for determination of enrofloxacin in rabbit's eyes tissues and fluids was in agreement with the results obtained from the microbiological method.

\section{RESULTS AND DISCUSSION}

Physicochemical properties of ketorolac tromethamine preparations.

The viscosity of prepared eye drops, gel and ointments

The values of viscosity of eye gel, drops and ointments were illustrated in Table (2). It was noted that, sod CMC gel showed a higher viscosity value than sod CMC eye drops which are $1256,1019.8 \mathrm{~m}$ pa.s, respectively. Also, for ointments, PVA showed the highest viscosity value $(2745.75 \mathrm{~m}$ pa.s). While, absorption base ointment showed the lowest viscosity value (784.5 $\mathrm{m}$ pa.s).

pH of the prepared formulations

The $\mathrm{pH}$ values of prepared formulae were shown in Table (2). These values of all formulations were in the range from 6.13 to 6.93 . So, the eye can tolerate these formulations with little discomfort. It was proved that, alkaline $\mathrm{pH}$ induced greater lacrimation than acidic $\mathrm{pH}$ in albino rabbits ${ }^{14}$.

\section{Drug content}

The obtained results are presented in Table (2). The percentage of ketorolac tromethamine content in all preparations was in the range of $98.5 \%$ to $100 \%$ of the drug content which complies with the official requirements ${ }^{15}$. 
Table 2: Physical evaluation of different ophthalmic preparations containing ketorolac tromethamine $(0.5 \% \mathrm{w} / \mathrm{w})$.

\begin{tabular}{|c|c|c|c|c|}
\hline \multicolumn{2}{|c|}{ Formulae } & \multirow{2}{*}{$\begin{array}{l}\mathrm{pH} \\
6.22\end{array}$} & \multirow{2}{*}{$\begin{array}{c}\begin{array}{c}\text { Drug } \\
\text { content } \\
(\% \mathrm{~W} / \mathrm{V})\end{array} \\
100\end{array}$} & \multirow{2}{*}{$\begin{array}{c}\text { Viscosity } \\
\text { (m pa.s) }\end{array}$} \\
\hline Drops & Sod. CMC & & & \\
\hline Gel & Sod. CMC & 6.58 & 100 & 1256 \\
\hline \multirow[b]{2}{*}{ Ointments } & PVA & 6.2 & 99.8 & 2745.75 \\
\hline & Absorption base & 6.87 & 98.5 & 784.5 \\
\hline \multirow{3}{*}{ Ocuserts } & HPMC & 6.5 & 100 & - \\
\hline & Gelatin & 6.13 & 100 & - \\
\hline & Carbopol $934 \&$ sod CMC & 6.93 & 99.9 & - \\
\hline
\end{tabular}

In-vitro release characteristics of ketorolac tromethamine from ophthalmic preparations

Figures (1\&2) illustrate the release characteristics of ketorolac tromethamine from different ophthalmic eye drops, gel, ointments and ocuserts. The maximum amounts released of the drug after six hours from sod CMC drops and gel were; $23.12,13.27 \mathrm{mg}$, respectively. While, the amounts released of the drug from ophthalmic ointments were; 10.29, 0.296 for PVA and absorption base ointments, respectively. Also, the amounts released from ocuserts were 14.27, 18.48 and 8.97 for HPMC, gelatin and carbopol 934 \& sod CMC ocuserts, respectively.

The obtained results showed that, sod CMC eye drops exhibited a higher rate of drug release than sod CMC gel. This may be due to the low viscosity of the eye drops compared to gel which permits the rapid release of the drug from the preparation ${ }^{16}$. In addition, sod CMC eye drops showed a higher release rate than PVA ointment, this may be due to the high viscosity value of PVA ointment compared to sod CMC eye drops, which may retard the release of the drug from the base. This finding was in agreement with Hirano et al. ${ }^{17}$, who studied the effect of the viscosity on the release profile of ibuprofen from different bases. They concluded that, the higher the viscosity of the base, the slower the drug release. Also, they reported that, the increase of viscosity of the vehicle is accompanied by a reduction in the amount of the drug released, and added that, the increase in the viscosity of the base will impart a more closed barrier resisting drug transfer to the outer surface and this will retard the movement of the drug molecules to the external release medium. 


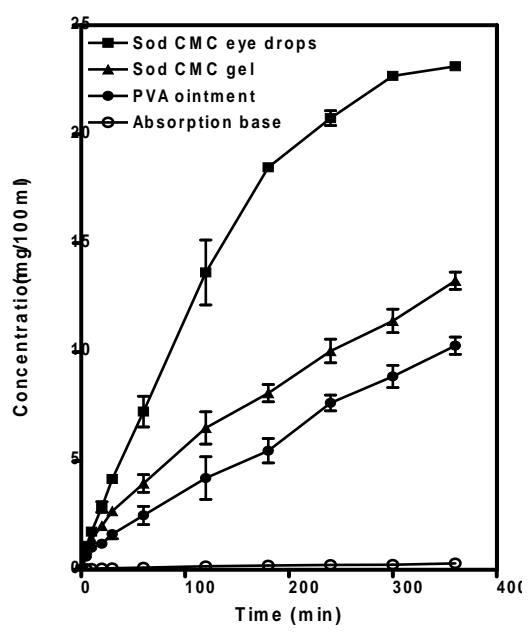

Fig. 1: In-Vitro release profiles of ketorolac tromethamine from various ophthalmic preparations at $37^{\circ} \mathrm{C}$ in phosphate buffer of $\mathrm{pH} 7.4$.

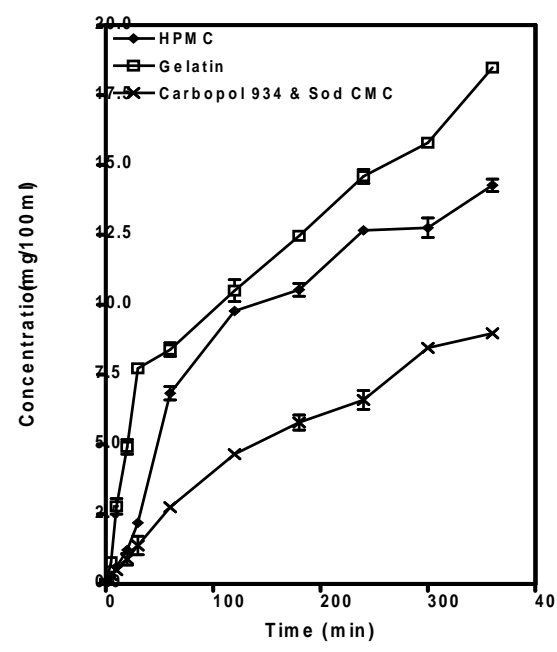

Fig. 2: In-Vitro release profiles of ketorolac tromethamine from various ophthalmic ocuserts at $37^{\circ} \mathrm{C}$ in phosphate buffer of $\mathrm{pH}$ 7.4
On the other hand, the absorption base ointment showed the least release rate compared to the all prepared formulations, despite of having lower viscosity value. This may be due to higher water solubility of the eye drops, gel and ocuserts and the higher lipophilicity of the ointment base. This finding was in agreement with that of El-Shaboury, et al. $^{18}$, who proved that, sod CMC gel exhibited the highest rate of drug release, while, hydrocarbon base showed the lowest one. The author attributed this result to the higher water solubility of sod CMC gel and the higher lipophilicity as well as the poor water miscibility of the hydrocarbon base. So, the amounts of the drug released from ophthalmic drops, gel, ointments can be arranged in the following order; Eye drops > gel > PVA ointment > absorption base ointment.

The amount of ketorolac tromethamine released from eye drops was higher than that released from ocuserts, then followed by eye gel and finally, eye ointments which showed the lowest amounts of the drug released. This finding was in agreement with that of El-Dahan ${ }^{13}$, who proved that, the amount of naproxen released from eye drops was higher than that released from ocuserts and followed by that released from eye gels.

The results of the drug release from ocuserts showed that, the amount of the drug released from gelatin ocuserts was higher than that released from HPMC ocuserts, then 
finally carbopol 934 \& sod CMC ocuserts which showed the lowest amount of the drug released from ocuserts. So the ocusert bases could be arranged in this order according to the higher drug release; Gelatin > HPMC > Carbopol 934 \& sod. CMC.

Shaker $^{19}$ proved that, phenylephrine hydrochloride could be formulated in the form of ocuserts using different polymers, and the highest amount of drug released was shown by HPMC followed by MC ocular film then Eudragit. This may be due to the hydrophilic nature as well as water solubility of HPMC and MC films in contrast to the water insolubility of Eudragit ocular films.

Manvi et. $a .^{20}$, exerted many efforts to prepare ocuserts of ketorolac tromethamine using gelatin. Their results indicated that, gelatin polymeric ocuserts containing ketorolac tromethamine achieved the objectives of increased contact time, prolonged release, decreased frequency of administration and thus improve the patient compliance.

\section{Kinetic analysis of the release data}

In order to determine the mechanism of ketorolac tromethamine release from different ophthalmic preparations, the in-vitro release data were analyzed mathematically according to: zeroorder, first order and Higuchi diffusion model. The results were represented in Table (3).

From the kinetic estimation of the release data, it was found that, the best fitting linear relations with the highest correlation coefficient were found with Higuchi diffusion equation for all formulations (0.998, $0.9877,0.963,0.961$, and 0.992 for sod CMC gel, absorption base ointment, HPMC ocuserts, gelatin ocuserts and carbopol 934 \& sod CMC ocuserts, respectively, except two formulations were found to obey first-order release kinetics which are sod CMC eye drops and PVA ointment with correlation coefficients of $(0.994,0.999)$, respectively.

The slopes of lines when $\log \mathrm{Q} / \mathrm{A}$ was plotted versus $\log \mathrm{t}$ was more than 0.5 . So, the release pattern can be described by non-Fickian diffusion kinetics. From the obtained results, it was found that, sod CMC eye drops show the highest diffusion coefficient and permeability coefficient $\left(10 \times 10^{-4}\right.$, 0.019 ug. $\mathrm{cm}^{-2} \cdot \mathrm{min}^{-1}$, respectively). While, the lowest values for diffusion coefficient and permeability coefficients were obtained from absorption base and carbopol 934 \& sod CMC ocuserts. The lowest value of partition coefficients was shown by sod CMC drops (0.095), while, the highest value was shown by the absorption base ointment (9.9).

\section{Stability study}

The different formulae were found to be physically stable as they did not show any color or odor changes or syneresis after the storage. While, for gelatin ocuserts, it was noted that, after the storage period it was hardened and cracked. The $\mathrm{pH}$ of the prepared formulae remained unchanged during all the storage period at different temperatures. 
Table 3: Kinetic modeling of ketorolac tromethamine released from different preparations through cellulose membrane barrier.

\begin{tabular}{|c|c|c|c|c|c|c|c|c|c|}
\hline \multirow{2}{*}{\multicolumn{3}{|c|}{$\begin{array}{l}\text { Formulation } \\
\text { Parameter }\end{array}$}} & Drops & Gel & \multicolumn{2}{|c|}{ Ointments } & \multicolumn{3}{|c|}{ Ocuserts } \\
\hline & & & \multirow{2}{*}{$\begin{array}{c}\text { Sod CMC } \\
0.935\end{array}$} & \multirow{2}{*}{$\begin{array}{c}\text { Sod CMC } \\
0.9863\end{array}$} & \multirow{2}{*}{$\begin{array}{c}\text { PVA } \\
0.9962\end{array}$} & \multirow{2}{*}{$\begin{array}{c}\begin{array}{c}\text { Absorption } \\
\text { base }\end{array} \\
0.9692\end{array}$} & \multirow{2}{*}{$\begin{array}{c}\text { HPMC } \\
0.879\end{array}$} & \multirow{2}{*}{$\begin{array}{c}\text { Gelatin } \\
0.906\end{array}$} & \multirow{2}{*}{$\begin{array}{c}\begin{array}{c}\text { Carbopol } \\
934 \\
\text { Sod CMC }\end{array} \\
0.97\end{array}$} \\
\hline Zero & $\mathrm{r}_{\mathrm{o}}$ & & & & & & & & \\
\hline order & Ko (mg & $\left.\operatorname{in}^{-1}\right)$ & 0.0675 & 0.0341 & 0.0274 & 0.0007 & 0.04 & 0.04 & 0.024 \\
\hline \multirow{3}{*}{$\begin{array}{l}\text { First } \\
\text { order }\end{array}$} & \multicolumn{2}{|l|}{$\mathrm{r}_{1}$} & 0.9949 & 0.9974 & 0.9994 & 0.9695 & 0.0949 & 0.96 & 0.98 \\
\hline & \multicolumn{2}{|l|}{$\mathrm{K}_{1}$} & 0.0075 & 0.0018 & 0.0013 & 0.0011 & 0.0035 & 0.004 & 0.0013 \\
\hline & \multicolumn{2}{|c|}{$\mathrm{t}^{1 / 2(\min )}$} & 92.4 & 376.25 & 501.6 & 602 & 2.13 & 173.25 & 533 \\
\hline \multirow{4}{*}{$\begin{array}{l}\text { Higuchi } \\
\text { diffusion } \\
\text { equation }\end{array}$} & \multirow{2}{*}{$\begin{array}{l}\text { Q/A vs. } \\
t^{1 / 2}\end{array}$} & $\mathrm{r}_{\mathrm{h}}$ & 0.985 & 0.998 & 0.9789 & 0.9877 & 0.963 & 0.961 & 0.992 \\
\hline & & $\begin{array}{l}\text { D (ug. } \mathrm{cm}^{-2} \text {. } \\
\text { min }^{-1}\end{array}$ & $10 \times 10^{-4}$ & $5 \times 10^{-4}$ & $2 \times 10^{-4}$ & $1 \times 10^{-4}$ & $4 \times 10^{-4}$ & $5 \times 10^{-4}$ & $1 \times 10^{-4}$ \\
\hline & \multirow{2}{*}{$\begin{array}{l}\log \\
\text { Q/A vs. } \\
\log _{t}\end{array}$} & $r_{h}$ & 0.9937 & 0.9985 & 0.9891 & 0.9879 & 0.95 & 0.88 & 0.994 \\
\hline & & Slope & 0.755 & 0.6191 & 0.6665 & 0.4661 & 0.92 & 0.6 & 0.8 \\
\hline \multicolumn{3}{|c|}{$\operatorname{Pm} \times 10^{-4}$ (ug. $\mathrm{cm}^{-2} \mathrm{~min}^{-1}$ ) } & 0.009 & 0.0009 & 0.0007 & 0.0001 & 0.001 & 0.001 & 0.0006 \\
\hline \multicolumn{3}{|l|}{$\mathrm{Kp}$} & 0.095 & 0.096 & 0.19 & 9.90 & 0.14 & 0.113 & 0.339 \\
\hline
\end{tabular}

\section{Where;}

$\mathrm{K}=$ Rate constant

$\mathrm{Kp}=$ Partition coefficient

$\mathrm{R}=$ Correlation coefficien

$\mathrm{D}=$ Diffusion coefficient.

$\mathrm{Pm}=$ Permeability coefficient 
The U.V scanning revealed the absence of any interaction or decomposition products of the drug in the tested preparations. With regard to ketorolac tromethamine content, sod CMC eye drops containing $0.25 \%$, showed drug content of 99.7\% after their storage for six months at $25^{\circ} \mathrm{C}$, while those stored at $35^{\circ} \mathrm{C}$ and $45^{\circ} \mathrm{C}$ showed drug content of $99.65 \%$ and $99.6 \%$, respectively. So, there are small or nearly no changes in the drug content of the prepared eye drops throughout the study period. This was in accordance with the results obtained by Soliman ${ }^{11}$, who proved that, atropine sulfate eye drops containing $0.5 \%$ sod CMC and $10 \%$ PVP $\mathrm{K}_{25}$ could be stored for long time (two years) without degradation of the drug or complexation of their components.

In addition, the tested gel of sod CMC, which was subjected to accelerated stability tests, showed a little decrease of the drug content percentage to $99.5 \%$ of its initial content after storage for 6 months at $45^{\circ} \mathrm{C}$. So, the drug content in this gel did not significantly changed when stored at $25^{\circ} \mathrm{C}, 35^{\circ} \mathrm{C}$ and $45^{\circ} \mathrm{C}$ for 6 months. In another word, the drug was nearly equally stable in the tested ophthalmic gel.

The ocuserts containing 5\% HPMC, showed drug content of 96.8\% after storage for six months at $25^{\circ} \mathrm{C}$, while, those stored at $35^{\circ} \mathrm{C}$ and $45^{\circ} \mathrm{C}$ showed drug contents of $96.1 \%$ and $95.2 \%$, respectively. Also, for gelatin ocuserts, it showed drug content of $97.8 \%$ after the storage for six months at $25^{\circ} \mathrm{C}$, while, those stored at $35^{\circ} \mathrm{C}$ and $45^{\circ} \mathrm{C}$ showed drug contents of $97.5 \%$ and $97 \%$, respectively. Finally, for carbopol 934 $\&$ sod $\mathrm{CMC}$, it showed drug content of $99.1 \%$ after storage for six months at $25^{\circ} \mathrm{C}$. While, those stored at $35^{\circ} \mathrm{C}$ and $45^{\circ} \mathrm{C}$ showed drug contents of $99 \%$ and $98.5 \%$. So, there was a slight change or nearly no changes in the drug content in the prepared ocuserts throughout the study period.

The percentage of ketorolac tromethamine content in these preparations was in the range which complies with the official requirements (USP XXIV). This was in agreement with El-Dahan ${ }^{13}$, who proved that, naproxen could be formulated in ophthalmic drops, gels and ocuserts using sod. CMC and HPMC. In addition, the prepared formulae were stable after storage for six months at the temperatures of $25^{\circ} \mathrm{C}, 35^{\circ} \mathrm{C}$ and $45^{\circ} \mathrm{C}$.

On the other hand, the ointments showed great changes in the percentages of the drug content. These results proved that, after six months, the percentages of the drug contents were $81 \%$ (for PVA base) and $78.65 \%$ (for absorption base). The degradation may affect the biological activity and causes a decrease in the initial concentration of the product which may be permitted within a range of not more than $10 \%{ }^{19}$

The kinetic analysis of the data to determine the mechanism of degradation, $t_{50}$ and $t_{90}$ was illustrated in Table (4). Analysis of data 
Table 4: Degradation rate constant $(\mathrm{K})$, half life $\left(\mathrm{t}_{50}\right)$ and expiration date $\left(\mathrm{t}_{90}\right)$ of ketorolac tromethamine ophthalmic preparations after storage for six months at different temperatures.

\begin{tabular}{|c|c|c|c|c|c|c|c|c|c|}
\hline $\begin{array}{c}\text { Temperature of } \\
\text { storage }\end{array}$ & \multicolumn{3}{|c|}{$25^{\circ} \mathrm{C}$} & \multicolumn{3}{|c|}{$35^{\circ} \mathrm{C}$} & \multicolumn{3}{|c|}{$45^{0} \mathrm{C}$} \\
\hline Formulae & $\begin{array}{c}\mathrm{K} \\
\text { Month }^{-1}\end{array}$ & $\begin{array}{c}\mathrm{t}_{50} \\
\text { Month }\end{array}$ & $\begin{array}{c}\mathrm{t}_{90} \\
\text { Month }\end{array}$ & $\begin{array}{c}\mathrm{K} \\
\text { Month }^{-1}\end{array}$ & $\begin{array}{c}\mathrm{t}_{50} \\
\text { Month }\end{array}$ & $\begin{array}{c}\mathrm{t}_{90} \\
\text { Month }\end{array}$ & $\begin{array}{c}\text { K } \\
\text { Month }^{-1}\end{array}$ & $\begin{array}{c}\mathrm{t}_{50} \\
\text { Month }\end{array}$ & $\begin{array}{c}\mathrm{t}_{90} \\
\text { Month }\end{array}$ \\
\hline Sod CMC eye drops & $0.6 \times 10^{-3}$ & 1003 & 151.9 & $0.6 \times 10^{-3}$ & 1003 & 151.9 & $0.6 \times 10^{-3}$ & 1003 & 151.97 \\
\hline Sod CMC gel & $0.6 \times 10^{-3}$ & 1003 & 151.9 & $1.1 \times 10^{-3}$ & 601.8 & 91.18 & $1.1 \times 10^{-3}$ & 601.8 & 91.18 \\
\hline PVA base ointment & $27 \times 10^{-3}$ & 25.07 & 3.7 & $34 \times 10^{-3}$ & 20.06 & 3.03 & $36 \times 10^{-3}$ & 18.8 & 2.84 \\
\hline $\begin{array}{c}\text { Absorption base } \\
\text { ointment }\end{array}$ & $25 \times 10^{-3}$ & 27.3 & 4.1 & $32 \times 10^{-3}$ & 21.4 & 3.25 & $36 \times 10^{-3}$ & 18.8 & 2.84 \\
\hline HPMC ocuserts & $4 \times 10^{-3}$ & 150.4 & 22.7 & $6 \times 10^{-3}$ & 100.3 & 15.19 & $7 \times 10^{-3}$ & 91.18 & 13.8 \\
\hline Gelatin ocuserts & $3 \times 10^{-3}$ & 188.0 & 28.4 & $4 \times 10^{-3}$ & 167.1 & 25.3 & $4 \times 10^{-3}$ & 150.4 & 22.7 \\
\hline $\begin{array}{l}\text { Carbopol } 934 \& \text { Sod } \\
\text { CMC ocuserts }\end{array}$ & $1 \times 10^{-3}$ & 50.15 & 7.5 & $1 \times 10^{-3}$ & 376.1 & 56.9 & $2 \times 10^{-3}$ & 300.9 & 45.59 \\
\hline
\end{tabular}

\section{Where;}

$\begin{array}{lll}\mathrm{K} & = & \text { Degradation rate constant. } \\ \mathrm{t}_{50} & = & \text { Time after which } 50 \% \text { of ketorolac tromethamine content } \\ & = & \text { Remained. } \\ \mathrm{t}_{90} & & \text { Time after which } 90 \% \text { of ketorolac tromethamine content } \\ & & \text { remained } \\ \text { Sod CMC } & = & \text { Sodium carboxymethyl cellulose. } \\ \text { PVA } & = & \text { Polyvinyl alcohol. }\end{array}$


revealed that, the first-order degradation kinetics of ketorolac tromethamine was fitted for all investigated ophthalmic preparations. It was noted that, the degradation rate constants of ketorolac tromethamine have low values at low temperatures $\left(25^{\circ} \mathrm{C}\right)$, while, it has higher values at high temperatures $\left(45^{\circ} \mathrm{C}\right)$. The degradation rate constants $(\mathrm{K})$ at $25^{\circ} \mathrm{C}$ for the preparations were; 0.0006, 0.0006, 0.027, 0.025, 0.004, 0.003 and 0.001 month $^{-1}$ for sod CMC eye drops, sod CMC gel, PVA base, absorption base, HPMC ocuserts, gelatin ocuserts and carbopol 934 \& sod CMC ocuserts, respectively.

The degradation rate constants at $45^{\circ} \mathrm{C}$ were; 0.0006, 0.0011, 0.036, $0.036,0.007,0.004$ and 0.002 month

${ }^{1}$ using the same above preparations in the same arrangement. The half-life period for ketorolac tromethamine formulations stored at $45^{\circ} \mathrm{C}$ were; $1003.04,601.8,18.8,18.8$, 91.18, 150.4 and 300.9 months using sod CMC eye drops, sod CMC gel, PVA base, absorption base, HPMC ocuserts, gelatin ocuserts and carbopol $934 \&$ sod CMC ocuserts, respectively.

The results indicated that, the formulae containing drug in both PVA ointment and absorption base ointment showed, the highest degradation rate constant $(0.036$ month $^{-1}$ at $45^{\circ} \mathrm{C}$ ) and the shortest half-life period (18.8 months).

The expiration dates of ketorolac tromethamine at $25^{\circ} \mathrm{C}$ were 151.97 , $151.97,3.79,4.1,22.7,28.4$ and 7.5 months using sod CMC eye drops, sod CMC gel, PVA ointment, absorption base ointment, HPMC ocuserts, gelatin ocuserts and carbopol 934 \& sod CMC ocuserts, respectively.

\section{In-vivo study}

The concentration of ketorolac tromethamine uptaken by eye tissues and aqueous humor from ophthalmic eye drops, gel, ointment and ocuserts were graphically illustrated in Figures (3-7).

The maximum concentration of ketorolac tromethamine in different rabbits eye tissues $\left(\mathrm{C}_{\max }\right)$ were; 26.1, $64.33,35.08$ and $78.45 \mu \mathrm{g} / \mathrm{gm}$ in conjunctiva, 12.49, 36.77, 28.21 and $37.08 \mu \mathrm{g} / \mathrm{gm}$ in cornea, 10.52, 32.28, 17.4 and $33.85 \mu \mathrm{g} / \mathrm{gm}$ in iris-ciliary body and 3.29, 9.19, 7.01 and 10.52, $\mu \mathrm{g} / \mathrm{gm}$ in aqueous humor for sod. CMC eye drops, sod CMC gel, PVA ointment and gelatin ocuserts, respectively (Table 5). These obtained results showed that, the higher concentration of the drug was uptaken in conjunctiva followed by cornea, iris-ciliary body, then aqueous humor from all tested preparations. This may be due to the direct contact of these tissues with the tear pool which housing the drug.

This finding was in agreement with the results obtained by ElShaboury et al. ${ }^{18}$, who found the same results on studying the ocular availability of bromhexine from ophthalmic solution and gels. Also, Shaker ${ }^{19}$ stated that, the highest concentration of ciprofloxacin hydrochloride found in conjunctival tissue may be interpreted in term of drug protein binding in the tissues rich in protein content. 


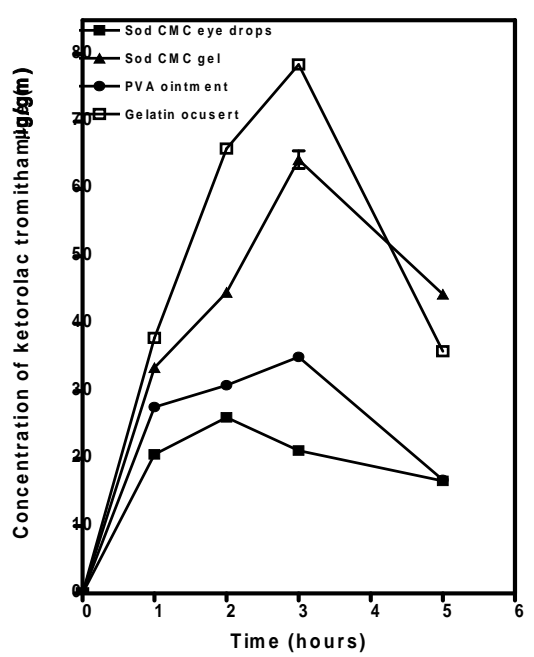

Fig. 3: Availability of ketorolac tromethamine in conjunctiva from various ophthalmic preparations.

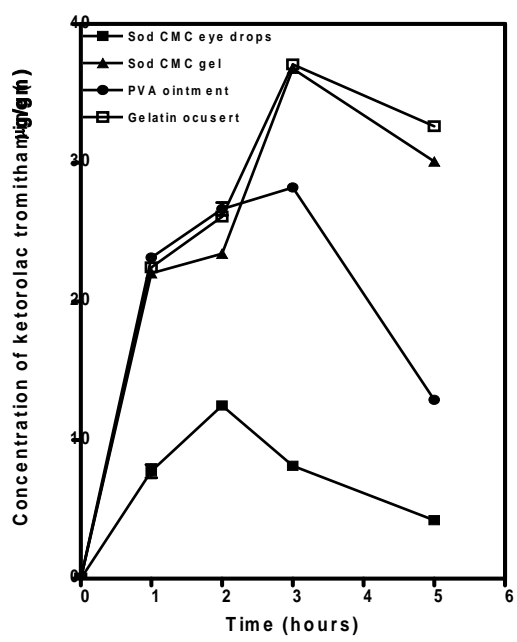

Fig. 4: Availability of ketorolac tromethamine in cornea from various ophthalmic preparations.

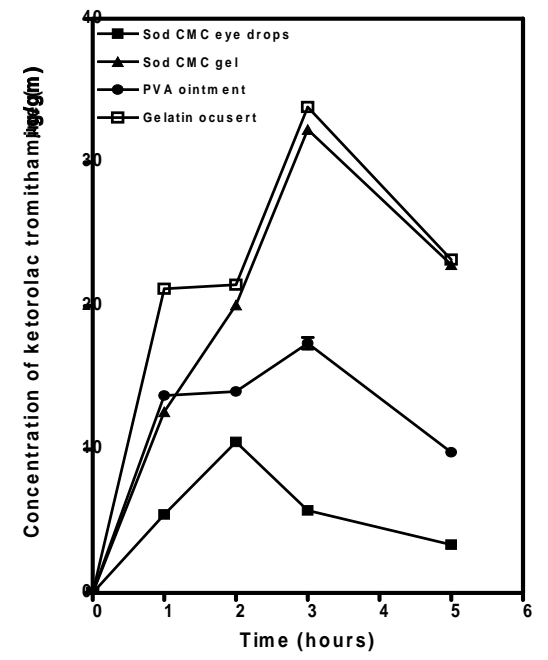

Fig. 5: Availability of ketorolac tromethamine in iris-ciliary body from various ophthalmic preparations.

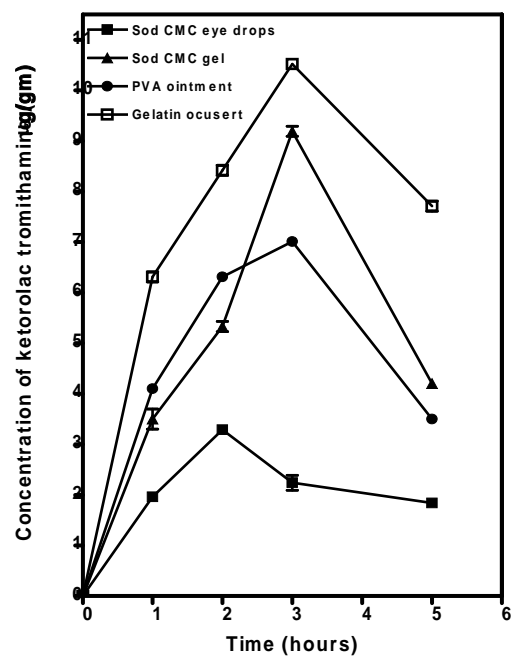

Fig. 6: Availability of ketorolac tromethamine in aqueous humor from various ophthalmic preparations. 


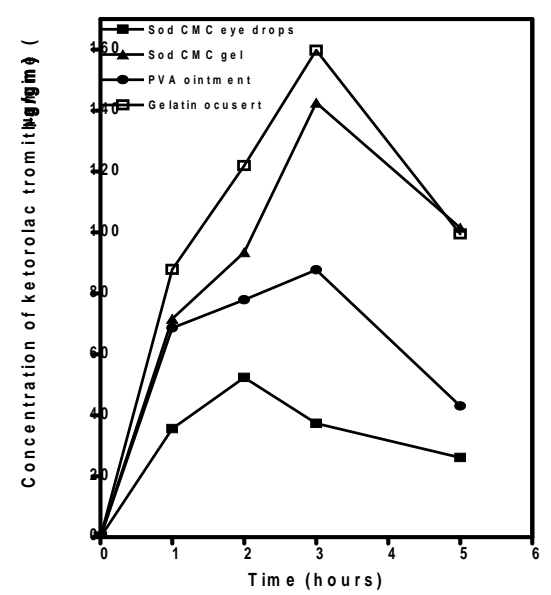

Fig. 7: Total ocular availability of ketorolac tromethamine in different rabbit's eye tissues and aqueous humor from various ophthalmic preparations.

However, in deeper tissues (iris ciliary body and aqueous humor), the drug was found to be in a higher concentration in iris- ciliary body structure than in aqueous humor. This is because the drug that appears in aqueous humor comes from iris ciliary body or endothelial surface of the cornea as reported by Habib et $a .^{8}$.

The obtained results showed that, the peak time for maximum drug concentration $\left(\mathrm{T}_{\max }\right)$ from Sod CMC eye drops was two hours and that from Sod CMC gel, PVA ointment and gelatin ocuserts was three hours in all tissues after application of these formulations (Table 5). From the obtained results, Sod CMC gel had longer peak time than Sod CMC eye drops. This result was in agreement with Shaker ${ }^{19}$ who proved that, the gels containing ciprofloxacin hydro- chloride have a longer peak time (2 hours) than the ophthalmic solution (1 hour). This may be due to retardation of the drug release from the gels as compared to ophthalmic solutions, which have less controlling effect on the drug release.

Also, PVA ointment and gelatin ocusert have the same peak time as Sod CMC gel, which is longer peak time than that of Sod CMC eye drops. This could be explained by the prolongation of the drug contact time with the eye tissues from these formulations.

Soliman $^{11}$ reported that, the semisolid preparations (gels, and ointments) containing atropine sulfate had the longer peak time (3 hours) than ophthalmic solutions (2 hours). This is because; gels and ointments retard the release of the drug compared with the ophthalmic solutions which have less controlling effect on the drug release. Also, it was reported by Sieg \& Robinson ${ }^{21}$, that the peak concentration of fluorometholone ointment into rabbits eyes not reached until 3 hours after topical dosing.

The values of area under timeconcentration curve of ketorolac tromethamine in different rabbits eye tissues (AUC) were; 95.16, 385.45, 127.97 and $257.44 \mu \mathrm{g} . \mathrm{hr} / \mathrm{gm}$ in conjunctiva, 36.48, $135.69,105.02$ and $101.8 \mu \mathrm{g} . \mathrm{hr} / \mathrm{gm}$ in cornea, 27.97, $103.98,63.68$ and $89.65 \mu \mathrm{g} . \mathrm{hr} / \mathrm{gm}$ in iris-ciliary body, and 9.45, 26.81, 24.42 and $38.22 \mu \mathrm{g} . \mathrm{hr} / \mathrm{gm}$ in aqueous humor for sod. CMC eye drops, sod CMC gel, PVA ointment and gelatin ocuserts, respectively (Table 6). 
Table 5: Maximum peak concentration and peak time of ketorolac tromethamine ophthalmic preparations.

\begin{tabular}{||c|c|c|c|c|c|c|c|c||}
\hline \multirow{2}{*}{ Formulae } & \multicolumn{6}{|c||}{ Peak concentration and peak time of ketorolac tromethamine } \\
ophthalmic formulations
\end{tabular}

Table 6: Area under the curve of ketorolac tromethamine ophthalmic preparations for each tissue.

\begin{tabular}{|l|c|c|c|c||}
\hline \multirow{2}{*}{ Formulae } & \multicolumn{4}{|c||}{ AUC ( $\mu \mathrm{g} . \mathrm{hr} / \mathrm{gm})$} \\
\cline { 2 - 5 } & $\begin{array}{c}\text { Sod CMC } \\
\text { eye drops }\end{array}$ & $\begin{array}{c}\text { Sod CMC } \\
\text { gel }\end{array}$ & $\begin{array}{c}\text { PVA } \\
\text { ointment }\end{array}$ & $\begin{array}{c}\text { Gelatin } \\
\text { ocusert }\end{array}$ \\
\hline Conjunctiva & 95.16 & 385.45 & 127.97 & 257.44 \\
\hline Cornea & 36.48 & 135.69 & 105.02 & 101.8 \\
\hline $\begin{array}{l}\text { Iris-ciliary } \\
\text { body }\end{array}$ & 27.97 & 103.98 & 63.68 & 89.65 \\
\hline $\begin{array}{l}\text { Aqueous } \\
\text { humor }\end{array}$ & 9.45 & 26.81 & 24.42 & 38.22 \\
\hline
\end{tabular}

$\begin{array}{lll}\text { Where; } & & \\ \text { PVA } & = & \text { polyvinyl alcohol } \\ \text { Sod. CMC } & = & \text { sodium carboxymethylcellulose }\end{array}$


These obtained results showed that, the higher value of the drug was obtained in conjunctiva followed by cornea, iris-ciliary body, then aqueous humor from all tested preparations. This may be due to the direct contact of these tissues with the tear pool which housing the drug.

The total availability of the drug in rabbits eye tissues after two hours was presented in Table (7) and illustrated in Figure (7). It was 52.4 $\mu \mathrm{g} / \mathrm{gm}$ for sod. CMC eye drops. While, the total availability of the drug in eye tissues after three hours was $142.57,87.7$ and $159.9 \mu \mathrm{g} / \mathrm{gm}$ for sod CMC gel, PVA ointment and gelatin ocuserts, respectively. Thus, the total availability and AUC of the drug from the tested formulations was in the following order: gelatin ocuserts > sod CMC gel > PVA ointments > sod. CMC eye drops. This was in agreement with Shaker ${ }^{19}$ who proved that the total availability of ciprofloxacin hydrochloride from the tested formulations was in the following order: ocuserts > ophthalmic gel > ophthalmic solutions.

Also, this was in agreement with Malhotra \& Majumdar ${ }^{7}$ who studied the in-vivo ocular availability of ketorolac tromethamine following the ocular instillation of aqueous, oil, and ointment formulations to normal rabbit's eyes tissues. They found that, ointment formulation provided higher $\mathrm{C}_{\max }$ and AUC values compared with aqueous drops, although the drug contained in the dose of ointment was $50 \%$ of that contained in a dose of aqueous drops.

Table 7: Total ocular availability of ketorolac tromethamine from various ophthalmic preparations in rabbits eyes tissues and aqueous humor.

\begin{tabular}{|c|c|c|c|c|}
\hline Formulae & \multicolumn{4}{|c|}{$\begin{array}{l}\text { Total ocular availability of ketorolac tromethamine } \\
\text { in } \mu \mathrm{g} / \mathrm{gm}\end{array}$} \\
\hline $\begin{array}{l}\text { Time } \\
\text { (in hours) }\end{array}$ & $\begin{array}{l}\text { Sod CMC } \\
\text { eye drops }\end{array}$ & $\begin{array}{l}\text { Sod CMC } \\
\text { gel }\end{array}$ & $\begin{array}{c}\text { PVA } \\
\text { ointment }\end{array}$ & $\begin{array}{l}\text { Gelatin } \\
\text { ocusert }\end{array}$ \\
\hline 1 & 35.63 & $71.66^{\mathrm{a}}$ & $68.64^{a b}$ & $87.84^{\mathrm{abc}}$ \\
\hline 2 & 52.4 & $93.46^{\mathrm{a}}$ & $77.87^{\mathrm{ab}}$ & $121.95^{\mathrm{abc}}$ \\
\hline 3 & 37.32 & $142.57^{\mathrm{a}}$ & $87.7^{\mathrm{ab}}$ & $159.8^{\mathrm{abc}}$ \\
\hline 5 & 26.11 & $101.51^{\mathrm{a}}$ & $43.04^{\mathrm{ab}}$ & $99.48^{\mathrm{abc}}$ \\
\hline
\end{tabular}

Data are expressed as mean

a- Significantly different at $\mathrm{P}<0.0001$ compared with Sod CMC eye drops

b- Significantly different at $\mathrm{P}<0.0001$ compared with Sod CMC gel

c- Significantly different at $\mathrm{P}<0.0001$ compared with PVA ointment.

In all above-mentioned statistical comparisons, one way analysis of variance (ANOVA) followed by Tukey-Kramer Multiple comparisons test was adapted. 


\section{Conclusion}

From the obtained results, it could be concluded that:

- According to the released amounts from these ophthalmic preparations after six hours, they can be arranged in the following order; Eye drops > ocuserts > gel > ointments.

- Such formulations could be stored for 6 months at $25^{\circ} \mathrm{C}, 35^{\circ} \mathrm{C}, 45^{\circ} \mathrm{C}$, without physical or chemical degradations of the drug in the selected formulations, except for ointments containing PVA and absorption base which showed some changes in the drug content.

- The decomposition rate of ketorolac tromethamine followed the firstorder degradation kinetics. The most stable formula is sod CMC eye drops and gel, meanwhile, the less stable formulations are PVA and absorption base ointments.

- Ketorolac tromethamine was rapidly uptaken from ophthalmic solution than from gels, ointment and ocuserts. While, the ocular availability was improved by gels and ocuserts.

- The peak time of maximum ketorolac tromethamine concentration in rabbit's eye tissues and aqueous humor was two hours for sod CMC ophthalmic solution and three hours for sod CMC ophthalmic gel, PVA ointment and gelatin ocuserts.

- All tested formulations provided the highest $\mathrm{C}_{\max }$ of the drug in conjunctiva followed by cornea, iris-ciliary body, then aqueous humor and it could arranged as follows; gelatin ocuserts > sod CMC gel > PVA ointment > sod. CMC eye drops.

\section{REFERENCES}

1- V. H. L. Lee, Pharm. Int., 6, 135 (1985).

2- J. P. Kaur and M. Kanwar, Drug Dev. Ind. Pharm., 28, 473 (2002).

3- V. H. L. Lee, J. Swarbrick, M. A. Redell and D. C. Yang, Int. J. Pharm., 16, 163 (1983).

4- M. B. Raizman, Clin. Ther., 17, 882 (1995).

5- C. Madhu, P. J. Rix, M. J. Shackleton, T. G. Nguyen and D. D. Tang-Liu, J. Pharm. Sci., 85, 415 (1996).

6- T. L. Ling and D. L. Combs, ibid., 76, 289 (1987).

7- M. Malhotra and D. K. Majumdar, AAPS Pharm. Sci. Tech., 6, E523 (2005).

8- F. S. Habib and M. A. Attia, Acta. Pharm. Technol., 32, 133 (1986).

9- M. Y. Levy and S. Benita, Int. J. Pharm., 66, 29 (1990).

10- E. R. Garrett and R. F. Carper, J. Am. Pharm. Assoc., 44, 515 (1955).

11- O. A. Soliman, "Formulation and Evaluation of certain Drugs in Ophthalmic Preparations", "Master Thesis", Faculty of Pharmacy, Pharmaceutics Department, Mansoura University, Egypt (1990). 
12- S. R. Bushby and G. H. Hitchings, Br. J. Pharmacol. Chemother, 33, 72 (1968).

13- M. S. El-Dahan, "Pharmaceeutical Studies on the Formulation and Bioavailability of some Anti-inflammatory Drugs in Ophthalmic Preparations", "Master Thesis", Faculty of Pharmacy, Pharmaceutics Department, Mansoura University, Egypt (2005).

14- J. M. Conard, W. A. Reay, E. Polcyn and J. R. Robinson, J. Parent. Drug Assoc., 32, 149 (1978).

15- United States Pharmacopoeia, $27^{\text {th }}$ Revision, United States Pharmacopoeial Convention, Inc., U.S.A., 2004, p. 2325.

16- B. Brunner and P. Speiser, Arzneimittel Forschung, 20,1610 (1970).
17- E. Hirano, K. Morimoto, T. Takeeda, Y. Nakamoto and K. Morisaka, Chem. Pharm. Bull. (Tokyo), 28, 3521 (1980).

18- M. H. EL-Shaboury, E. M. Ramadan and Y. EL-Said, Mans. J. Pharm. Sci., 7, 224 (1991).

19- D. Shaker, "Formulation and Stability of some Topical Systems Containing certain Drugs", "Master Thesis", Faculty of Pharmacy, Pharmaceutics Department, Helwan University, Egypt (2000).

20- F. V. Manvi, B. K. Nanjwade and S. Hiremath, FIP. World. Congress, 62, 24 (2002).

21- J. W. Sieg and J. R. Robinson, J. Pharm. Sci., 64, 931 (1975). 